\title{
Regulation of $\mathrm{CD}^{+}{ }^{+} \mathrm{T}$ cell responses to retinal antigen by local FoxP3 ${ }^{+}$regulatory $T$ cells
}

\section{Scott W. McPherson, Neal D. Heuss and Dale S. Gregerson*}

Department of Ophthalmology, University of Minnesota, Minneapolis, MN, USA

\section{Edited by:}

Rachel R. Caspi, National Institutes of Health, USA

\section{Reviewed by:}

Matthias G. Von Herrath, La Jolla linstitute for Allergy and Immunology, USA

Igal Gery, National Eye Institute, USA

\section{*Correspondence:}

Dale S. Gregerson, Department of

Ophthalmology, University of

Minnesota, 2001 6th Street SE

Minneapolis, MN 55455, USA.

e-mail: grege001@umn.edu
While pathogenic CD4T cells are well known mediators of autoimmune uveoretinitis, CD8 T cells can also be uveitogenic. Since preliminary studies indicated that C57BL/6 mice were minimally susceptible to autoimmune uveoretinitis induction by CD8 T cells, the basis of the retinal disease resistance was sought. Mice that express $\beta$-galactosidase ( $\beta$ gal) on a retina-specific promoter (arrßgal mice) were backcrossed to mice expressing green fluorescent protein (GFP) and diphtheria toxin (DTx) receptor (DTR) under control of the Foxp3 promoter (Foxp3-DTR/GFP mice), and to T cell receptor transgenic mice that produce $\beta$ galspecific CD8 T cells (BG1 mice). These mice were used to explore the role of regulatory $T$ cells in the resistance to retinal autoimmune disease. Experiments with $T$ cells from double transgenic BG1 $\times$ Foxp3-DTR/GFP mice transferred into Foxp3-DTR/GFP $\times$ arrßgal mice confirmed that the retina was well protected from attempts to induce disease by adoptive transfer of activated BG1 T cells. The successful induction of retinal disease following unilateral intraocular administration of DTx to deplete regulatory $T$ cells showed that the protective activity was dependent on local, toxin-sensitive regulatory $T$ cells; the opposite, untreated eye remained disease-free. Although there were very few Foxp3 ${ }^{+}$regulatory ${ }^{\top}$ cells in the parenchyma of quiescent retina, and they did not accumulate in retina, their depletion by local toxin administration led to disease susceptibility. We propose that these regulatory $T$ cells modulate the pathogenic activity of $\beta$ gal-specific CD8 T cells in the retinas of arrßgal mice on a local basis, allowing immuno regulation to be responsive to local conditions.

Keywords: tregs, autoimmunity, retina, Foxp3, EAU

\section{INTRODUCTION}

The eye contains several tissues that are delicate and/or nonregenerative, rendering them susceptible to inflammatory or tissue destructive immune responses that can have serious consequences for visual function. In response, the eye has developed specialized anatomical features and physiological mechanisms that contribute to maintenance of protective immune functions while limiting non-specific, collateral tissue damage associated with immune responses (Gregerson, 1998; Streilein, 2003; Niederkorn and Wang, 2005; Caspi, 2006; Taylor, 2009; Hori et al., 2010).

Among ocular tissues, the retina is unique in that it is part of the central nervous system (CNS), but differs from brain and spinal cord by the absence of meninges and the lack of lymphatic drainage (Yamada et al., 1991; Cserr et al., 1992). The retina also contains high concentrations of tissue-specific proteins associated with visual transduction including interphotoreceptor retinoidbinding protein (IRBP), arrestin, and photoreceptor opsins. T cell recognition of retinal antigens $(\mathrm{Ag})$ can lead to experimental autoimmune uveoretinitis (EAU) when retinal immune privilege is breached by effector $\mathrm{T}$ cell responses. Conversely, the recognition of these $\mathrm{Ag}$ by $\mathrm{T}$ cells also forms the basis for those mechanisms of retinal immune privilege that are based on Ag-specificity (McPherson and Gregerson, 1994; Egwuagu et al., 1997; Gery and Egwuagu, 2002; Gregerson, 2002; Avichezer et al., 2003a; Ham et al., 2004;
Carson et al., 2006; DeVoss et al., 2006; Lambe et al., 2007; Heuss et al., 2012). The actions of regulatory $\mathrm{T}$ cells (Tregs) are increasingly recognized to contribute to the immune homeostasis of the eye, and retina (Wenkel and Streilein, 1998; Grajewski et al., 2006; Niederkorn, 2007; Silver et al., 2007; Stein-Streilein and Taylor, 2007; Caspi, 2008).

While multiple lineages of $\mathrm{T}$ cells are capable of immunosuppressive activity (Shevach et al., 2006; Jutel and Akdis, 2008), the $\mathrm{CD}^{+}{ }^{+} \mathrm{CD} 25^{+} \mathrm{Foxp}^{+}{ }^{+} \mathrm{T}$ cell is the prototypical Treg. Many of these Tregs develop in the thymus in response to self- $\mathrm{Ag}$ (natural Tregs, $\mathrm{nTregs}$ ), in part due to aire promotion of peripheral Ag expression by medullary thymic epithelial cells (mTEC; Sakaguchi, 2011). However, $\mathrm{CD} 4{ }^{+} \mathrm{CD} 25^{+} \mathrm{Foxp}^{+}$Tregs are also generated in the periphery from mature, naïve $\mathrm{CD} 4^{+} \mathrm{T}$ cells (induced Tregs, iTregs), and are thought to be important in modulating immune responses to microorganisms and autoimmune inflammation (Thorstenson and Khoruts, 2001; Curotto de Lafaille et al., 2004; Lohr et al., 2006; Apostolou et al., 2008). Using CD4 ${ }^{+} \mathrm{T}$ cell receptor transgenic mice ( $\beta$ gal TCR mice) specific for E. coli $\beta$ gal, in conjunction with mice expressing $\beta$ gal as a transgenic neo-self- $\mathrm{Ag}$ in the retina ( $\operatorname{arr} \beta g a l$ mice), we demonstrated that retinal expression of $\beta$ gal led to regulation of systemic immune responses to $\beta$ gal (Gregerson and Dou, 2002). This activity was subsequently attributed to the generation of Tregs in the periphery from naïve $\mathrm{CD} 4^{+}$precursors, 
especially in lymphopenic hosts (Gregerson et al., 2008, 2009; McPherson et al., 2009; Heuss et al., 2012).

Although it is clear that newly generated iTregs provide protection from retinal autoimmunity, it is not clear how and where these iTregs are made and exert their effects. The $\beta$ gal antigen in arr $\beta$ gal mice is of retinal origin, but the site of Treg generation and expression of regulatory activity of the Bgal-specific Tregs remains uncertain. The interaction between Ag-bearing dendritic cells (DC) and T cells in draining LNs is a major mechanism for the generation of iTregs (DiPaolo et al., 2007). However, the highly restricted, tissue-specific expression of retinal $\beta$ gal combined with the apparent lack of lymphatic drainage from retina allows for the possibility that iTregs to retina-specific Ag might be generated and/or act in a local, tissue-specific manner. Evidence for induction of iTregs from naive $\mathrm{T}$ cells, but not committed $\mathrm{T}$ cells, following their injection into the posterior segment of the eye was recently shown (Zhou et al., 2012). Such a mechanism was consistent with our recent evidence for retinal DC that promoted production of iTregs that were recovered from quiet retina, and correlated the local antigen presenting cell (APC) activity with EAU susceptibility (Heuss et al., 2012).

While many studies have examined the effects of Foxp $3^{+}$Tregs on CD4 T cell mediated autoimmunity, relatively few have looked at Treg modulation of the activity of autoreactive CD8 T cells. In studies to investigate the origin and retinal-protective function of Tregs specific for retinal Ags, and establish their role in a CD8 T cell model of autoimmunity, we examined the activity of Tregs from $\beta$ gal-specific, CD8 TCR Tg mice in conjunction with arrßgal mice, and mice expressing a diphtheria toxin (DTx) receptor (DTR) and/or green fluorescent protein (GFP) under control of the Foxp3 promoter. Although Foxp $3^{+}$Tregs were rarely found in the parenchyma of the quiescent retina, local Treg activity was critical for protection of the retina from uveitogenic $\mathrm{CD} 8^{+} \mathrm{T}$ cells. Our results suggest that immune privilege of the retina is substantially dependent on Ag-specific Tregs that act locally. Although they are present in small numbers, they are sufficient to control the pathogenic and delayed-type hypersensitivity (DTH) activity of the uveitogenic CD8 T cells.

\section{MATERIALS AND METHODS \\ MICE}

Rod photoreceptor cell expression of $\beta$ gal on the arrestin promoter in arrßgal transgenic mice yields approximately $150 \mathrm{ng} \beta \mathrm{gal} / \mathrm{retina}$, $<0.5 \mathrm{ng} \mathrm{\beta gal} /$ pineal gland, and rare, unidentified $\mathrm{Bgal}^{+}$brain cells (Gregerson and Dou, 2002). No other sites of $\beta$ gal expression have been found. Arrßgal on the B6 background mice were generated from B10.A-arrßgal mice by backcrosses with normal B6 mice for greater than 10 generations. BG1 mice produce CD8 T cells expressing a transgenic $V \beta 7$ TCR specific for the $\mathrm{H} 2-\mathrm{K}^{\mathrm{b}}$-restricted epitope DAPIYTNV in Bgal (Donohue et al., 2006; Tewalt et al., 2009). Foxp3-GFP and Foxp3-DTR/GFP transgenic mice on the B6 background, which express GFP only or GFP and DTR under control of the Foxp3 promoter, respectively, have been described (Fontenot et al., 2005; Kim et al., 2007). Breeding stock was kindly provided by Dr. S. S. Way (University of Minnesota). BG1 mice were backcrossed to the arrßgal mice, and the Foxp3-DTR/GFP mice. Mice were handled in accordance with the Association for
Research in Vision and Ophthalmology (ARVO) Statement for the Use of Animals in Ophthalmic and Vision Research, and the University of Minnesota institutional animal care and use guidelines. Mice were housed under specific pathogen-free conditions.

\section{INJECTIONS INTO THE ANTERIOR CHAMBER OF THE EYE, OR SUBCUTANEOUS (S.C.)}

Diphtheria toxin and saline injections into the eye were done by the trans-corneal route into the anterior chamber (AC) as previously described (Lehmann et al., 2010). One microliter doses containing saline or $25 \mathrm{ng} / \mu \mathrm{l}$ DTx were given as indicated. DTx injections into the cheek were given s.c. using $25 \mathrm{ng}$ DTx in $10 \mu \mathrm{l}$ saline as indicated.

\section{CELL CULTURE AND PURIFICATION}

Pooled spleen and lymph node (LN) cell suspensions were prepared by tissue homogenization followed by filtration through a $70-\mu \mathrm{M}$ cell strainer. Lymphocytes were also prepared from whole blood. Red blood cells were lysed using $0.17 \mathrm{M} \mathrm{NH}_{4} \mathrm{Cl}$ and the remaining cells were washed twice in PBS and resuspended in X-Vivo 15 media (Lonza) supplemented with sodium pyruvate $(100 \mu \mathrm{g} / \mathrm{ml})$, L-glutamine $(784 \mu \mathrm{g} / \mathrm{ml})$, penicillin $(100 \mathrm{U} / \mathrm{ml})$, streptomycin $(0.1 \mathrm{mg} / \mathrm{ml}), \beta$-mercaptoethanol $(50 \mu \mathrm{M}), 1 \times \mathrm{MEM}$ non-essential amino acids, and $2 \%$ fetal calf serum (FCS; Sigma). All cultures were maintained at $37^{\circ} \mathrm{C}$ in an atmosphere of $6 \% \mathrm{CO}_{2}$. The BG1 CD8 $\mathrm{T}$ cells were isolated using a CD8 T cell isolation kit (MiltenyiBiotec) per manufacturer's protocols.

\section{FLOW CYTOMETRY}

Cells from spleen, LN, or peripheral blood were prepared as described above except that the final suspension was made in FACS buffer (PBS with 2\% FCS and $0.02 \%$ sodium azide). Fluorescentlabeled antibodies (BD Biosciences or eBioscience) were added to the cell suspensions, from 0.25 to $2.0 \mu \mathrm{l} / 10^{6}$ cells, and incubated on ice for $30 \mathrm{~min}$. The cells were washed, resuspended in FACS buffer, and analyzed on a FACS Calibur flow cytometer using Cell Quest (BD Biosciences) or FlowJo (Tree Star) software. Sorting of purified CD4 $\mathrm{T}$ cells into regulatory $\left(\mathrm{GFP}^{+}\right)$ or effector $\left(\mathrm{GFP}^{-}\right)$populations was done on a FACS Aria flow cytometer (BD Bioscience). For flow cytometry on the cells in the retina, mice were euthanized, perfused, and the retinas removed as described (Lehmann et al., 2010). The retinas were dissociated using a solution of $0.2 \mu \mathrm{g} / \mathrm{ml}$ Liberase/TM (Roche) and $0.05 \%$ DNase in DPBS, stained with indicated antibodies, and analyzed as described (Lehmann et al., 2010). Analysis of all the cells collected from a single retina comprised a single sample.

\section{CYTOKINE ASSAYS}

Cultures containing $5 \times 10^{5}$ unfractionated spleen/LN cells from BG1 mice were aliquoted in triplicate into 96 -well plates in final volume of $200 \mu \mathrm{l}$ with or without $\beta$ gal protein $(10 \mu \mathrm{g} / \mathrm{ml})$. Supernatants were harvested $48 \mathrm{~h}$ post stimulation and assayed for cytokines by cytometric bead array (BD Bioscience) per manufacturer's protocol.

\section{INDUCTION AND TRANSFER OF TREGS}

Foxp3-GFP mice were injected i.v. with $100 \mu \mathrm{g}$ of $\beta$ gal or bovine serum albumin (BSA) solubilized in PBS at $1 \mathrm{mg} / \mathrm{ml}$. At 8 days 
post-injection, $\mathrm{CD} 4^{+} \mathrm{T}$ cells were isolated from spleen and $\mathrm{LN}$ by negative selection, and sorted for $\mathrm{CD}^{+} 4^{+} \mathrm{GFP}^{+}$cells. The cells were washed and resuspended in PBS to $5 \times 10^{6} / \mathrm{ml}$. Recipient mice received $5 \times 10^{5}$ cells i.v.

\section{CELL TRANSFERS AND INDUCTION AND ANALYSIS OF AUTOIMMUNE DISEASE}

For transfer of activated T cells, purified lymphocytes from LN and spleen of BG1 mice, or BG1 × Foxp3-DTR/GFP transgenic mice, as indicated, were stimulated with their cognate peptide $(0.5 \mu \mathrm{M})$ and irradiated $(3000 \mathrm{R}) \mathrm{B} 6$ splenocytes at a 1:10 ratio in the presence of IL-6 ( $5 \mathrm{ng} / \mathrm{ml})$, IL-1 $(2.5 \mathrm{ng} / \mathrm{ml})$, and TGF $\beta$ ( $1 \mathrm{ng} / \mathrm{ml})$. IL-2 $(10 \mathrm{U} / \mathrm{ml})$ was added $48 \mathrm{~h}$ post stimulation and the cells were cultured an additional $6 \mathrm{~h}$. The cultures were washed and resuspended in PBS to a concentration of $2 \times 10^{7}$ cells $/ \mathrm{ml}$. Recipient mice were inoculated i.p. with 5-20 $\times 10^{6}$ cells. Prior to transfer, the indicated recipients were irradiated $(900 \mathrm{R})$ or depleted of $\mathrm{CD} 25^{+}$cells by anti-CD25 antibody (BioXcell, clone PC61, $500 \mu$ g given i.p. three times at 3 day intervals with the last dose given 3 days prior to $\mathrm{T}$ cell transfer). $\beta$ gal-specific $\mathrm{T}$ cells were also generated by s.c. immunization of mice with a single, hindlimb $200 \mu$ l dose containing $200 \mu \mathrm{g} \beta$ gal emulsified in complete Freund's adjuvant (CFA) containing $5 \mathrm{mg} / \mathrm{ml}$ M. tuberculosis (H37Ra, Sigma) followed by $0.5 \mu \mathrm{g}$ pertussis toxin (Sigma) per mouse given in $100 \mu \mathrm{l}$ saline i.p. At the indicated times post-transfer or post-immunization, the eyes were harvested, fixed in $10 \%$ buffered formalin, paraffin embedded, sectioned ( $5 \mu \mathrm{M})$, and stained with H\&E. The slides were examined in a masked fashion, and EAU severity was scored from 0 (no disease) to 5 (complete loss of photoreceptor cells plus damage to the inner layers of the retina) based on histopathological changes to the retina (Gregerson et al., 1993).

\section{ANALYSIS OF THE DELAYED-TYPE HYPERSENSITIVITY RESPONSE}

Analysis of the DTH response (ear swelling assay) was done by injection of $\beta \mathrm{gal}$ ( $50 \mu \mathrm{g}$ in $10 \mu \mathrm{l}$ ) into the ear pinna as previously described (Gregerson and Dou, 2002).

\section{GENERATION AND ANALYSIS OF RADIATION-BONE MARROW CHIMERAS}

Tibias and femurs were harvested from euthanized donor mice. Bone marrow (BM) was flushed out with calcium, magnesium-free phosphate-buffered saline (CMF-PBS), passed through a $70-\mu \mathrm{m}$ mesh filter, and resuspended in CMF-PBS. Red blood cells were lysed in $0.17 \mathrm{M} \mathrm{NH}_{4} \mathrm{Cl}$. The BM was washed with CMF-PBS and resuspended to $5 \times 10^{7}$ cells $/ \mathrm{ml}$. Recipient mice were given $1 \times 10^{7} \mathrm{BM}$ cells via i.p. injection. Recipient mice were irradiated with $1200 \mathrm{R}$ of total body irradiation, given as a split dose $\left({ }^{137} \mathrm{Cs}\right.$, $2 \times 600 \mathrm{R}$ with a 3 -h interval), prior to BM transfer. Chimerism was assayed after 19 weeks by flow cytometry for CD45.1 ${ }^{+}$and CD45.2 $2^{+}$cells in blood. Activated BG1 T cells were injected at $4.5 \times 10^{6}$ per recipient, and the eyes harvested 21 days later.

\section{RESULTS}

\section{ANALYSIS OF $\beta$ GAL-SPECIFIC TCR Tg MICE}

We previously described CD4 T cell TCR Tg mice specific for $\beta$ gal ( $\beta$ galTCR) on the B10.A background. When backcrossed to mice expressing $\beta$ gal in retina ( $\operatorname{arr} \beta$ gal $\times \beta$ galTCR mice), no spontaneous EAU was observed nor did immunization with $\beta$ gal in CFA produce EAU in the double transgenic mice (Gregerson et al., 2009; McPherson et al., 2009). $\mathrm{CD}^{+} 25^{+}$Tregs were found to contribute to the resistance to EAU. The potential participation of Tregs in modulating the pathogenesis of EAU mediated by CD8 T cells specific for the same target Ag in retina was sought using the $\beta$ gal-specific, BG1 CD8 TCR mice.

Analysis of $\mathrm{CD}^{+}$splenocytes from BG1 mice showed that BG1 $\mathrm{T}$ cells were highly enriched for $\mathrm{CD} 8^{+} \mathrm{V} \beta 7^{+}$cells (Figure 1A). To learn if BG1 $\mathrm{T}$ cells maintained a naïve phenotype in mice expressing retinal $\beta$ gal, we compared $\mathrm{T}$ cells from BG1 mice with $\mathrm{T}$ cells from $\mathrm{BG} 1 \times$ arr $\beta$ gal double transgenic mice for cell surface markers associated with Ag recognition. FACS analysis of $\mathrm{LN} \mathrm{CD}{ }^{+} \mathrm{V} 7^{+} \mathrm{T}$ cells showed similar expression levels of CD44, CD45RB, CD62L, and CD69 between BG1 mice and their double $\mathrm{Tg}$ counterparts (Figure 1B). The small number of $\mathrm{CD}^{+} \mathrm{V} \beta 7^{+} \mathrm{T}$ cells from non-Tg $\mathrm{B} 6$ mice had a higher frequency of $\mathrm{CD}_{4} 4^{+} 45 \mathrm{RB}^{+}$cells (Figure 1B). As a control for $\mathrm{T}$ cell activation, the BG1 mice were immunized with $\beta$ gal in CFA adjuvant. The $\mathrm{CD} 8^{+} \mathrm{V} \beta 7^{+} \mathrm{T}$ cells showed a substantial shift to expression levels associated with $\mathrm{T}$ cell activation, higher CD44, and CD69, and lower CD45RB and CD62L (Figure 1B). The level of $\mathrm{CD}_{25} 5^{+} \mathrm{FoxP}^{+} \mathrm{T}$ cells sampled from spleen was also similar between BG1 mice and their double Tg counterparts (Figure 1C), showing that the retinal expression of $\beta$ gal did not alter the levels of Tregs. The total number of Tregs in both strains was small, compared to the frequency found in normal B6 mice, possibly reflecting the limited repertoire in this mice (see below). Analysis of cytokines produced by Ag stimulation in vitro showed that BG1 T cells produced only small amounts of IL- 6 and IL-10, and a moderate amount of TNF $\alpha$ (Figure 1D). No spontaneous autoimmune disease was found in the retinas of BG1 $\times$ arr $\beta$ gal double Tg mice.

Analysis of Foxp3-GFP mice for the distribution of GFP ${ }^{+}$Tregs in PBL showed that approximately $3.5 \%$ of circulating $\mathrm{T}$ cells was $\mathrm{GFP}^{+}$(Figure 2A). Of these, greater than $97 \%$ of the $\mathrm{GFP}^{+}$cells was $\mathrm{CD}^{+}$. In the $\mathrm{BG} 1 \times$ Foxp3-GFP mice, approximately $1.7 \%$ of peripheral $\mathrm{T}$ cells was $\mathrm{GFP}^{+}$, and greater than $96 \%$ was $\mathrm{CD}^{+}$. Most of the $\mathrm{GFP}^{+} \mathrm{CD} 4^{+} \mathrm{T}$ cells in the $\mathrm{BG} 1$ mice also expressed the V $\beta 7$ TCR transgene (Figure 2B). Virtually all of the small number of $\mathrm{CD}^{+} \mathrm{GFP}^{+} \mathrm{T}$ cells were $\mathrm{V} \beta 7^{+}$. The Ag-specific activity of the $\mathrm{BG} 1 \mathrm{~T}$ cells lies in the $\beta$ gal-specific $\mathrm{V} \beta 7^{+}$population that responds to the class I-restricted DAPIYTNV epitope (Donohue et al., 2006; Tewalt et al., 2009). Activation of the BG1 cells with this peptide conferred pathogenic activity on them (see below).

\section{ACTIVATED BG1 T CELLS CAN BE PATHOGENIC IN TISSUES EXPRESSING $\beta$ GAL}

Several rodent models show EAU induction by adoptive transfer of activated CD4 ${ }^{+} \mathrm{T}$ cells specific for endogenous and transgenic retinal antigens (Gregerson et al., 1986, 1999; Rizzo et al., 1996; Su et al., 2001; Lambe et al., 2007). Conversely, few studies of EAU induction by $\mathrm{CD} 8 \mathrm{~T}$ cells have been reported (McPherson et al., 2003; Song et al., 2008). We showed that $\mathrm{Bgal}^{+}$retinal photoreceptor cells in B10.A mice were targets for autoimmune disease mediated by an oligoclonal line of activated, $\beta$ gal-specific $\mathrm{CD} 8^{+} \mathrm{T}$ cells (McPherson et al., 2003, 2006). BG1 T cells activated in vitro with their cognate $\beta$ gal peptide and transferred into arr $\beta$ gal mice produced minimal autoimmune disease in the untreated arr $\beta$ gal 

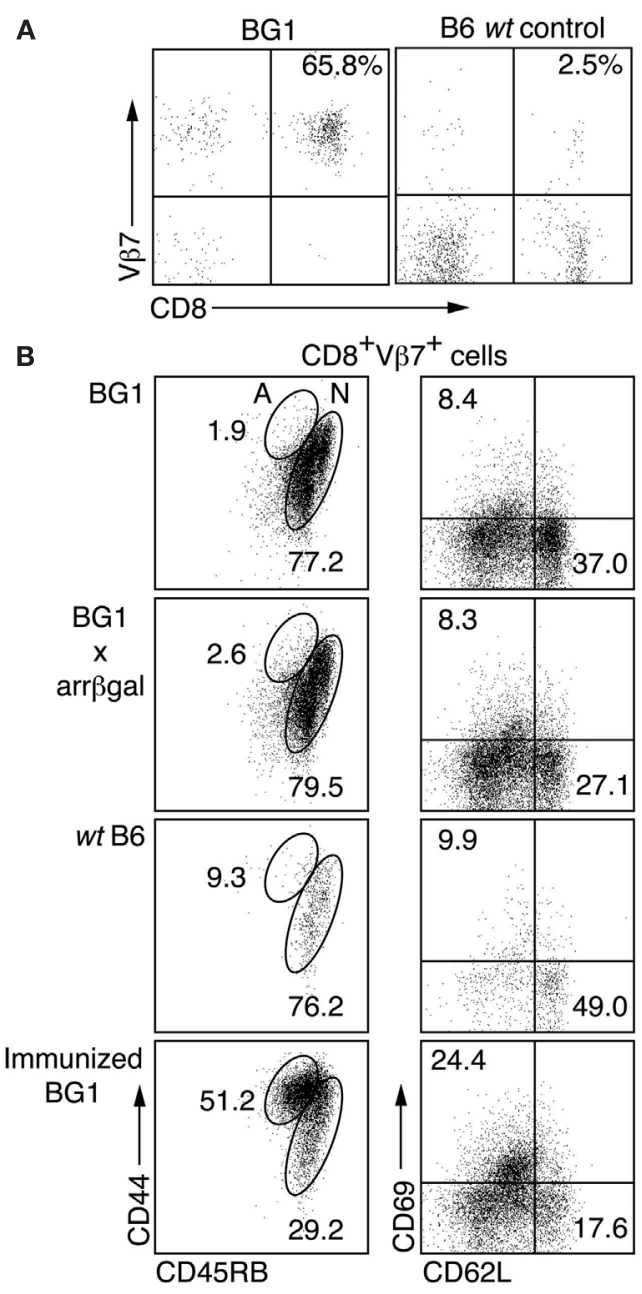

C
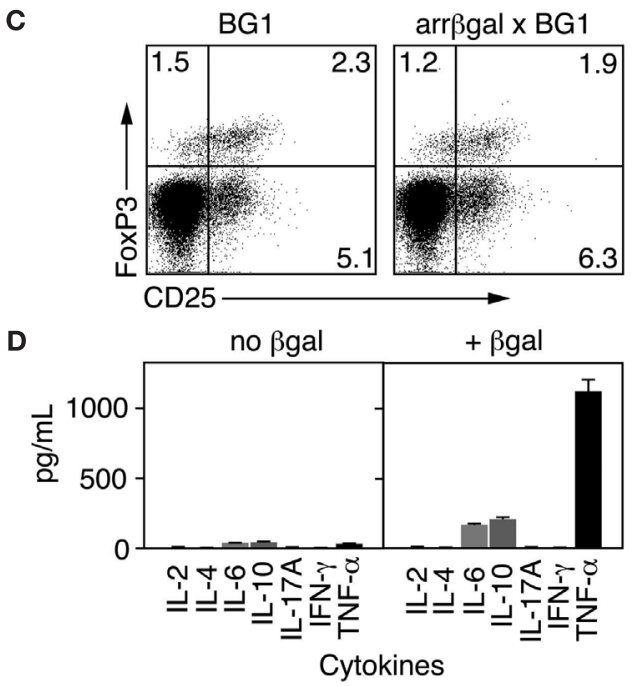

FIGURE 1 | Analysis of $\beta$ gal-specific BG1 TCR Tg mice. (A) FACS analysis of $\mathrm{CD}^{+}$splenocytes for $\mathrm{CD} 8$ and the clonotypic TCR $\beta$ chain for the BG1 Tg mice. (B) FACS analysis for cell surface molecules associated with $\mathrm{Ag}$ recognition. Lymphocytes were gated on $\mathrm{CD}^{+} \vee \vee \beta 7^{+}$and then analyzed for the indicated surface molecules. The percentage of cells having a naïve $(\mathrm{N})$ (Continued)

\section{FIGURE 1 | Continued}

or activated (A) phenotype is indicated. (C) Comparison of Treg levels in $B G 1$ vs. $B G 1 \times$ arr $\beta g a l$ mice. Splenic lymphocytes were gated on $\mathrm{CD} 4{ }^{+} \mathrm{CD} 90.2^{+}$cells and then analyzed for $\mathrm{CD} 25$ and Foxp3. Representative FACS plots are shown. $P$ values comparing the quadrants were determined by $t$-test, which showed that all were $>0.05(n=3)$. (D) Cytokine production of $\beta$ gal-specific BG1 TCR Tg splenocytes cultured with or without $\beta$ gal stimulation.

recipient mice, relative to normal controls (Figures 3A-D). Recipients that were pretreated with sub lethal irradiation (900 R) to produce lymphopenia, or depleted of $\mathrm{CD} 25^{+}$cells prior to BG1 $\mathrm{T}$ cell transfer showed a much higher incidence and severity of disease (Table 1; Figures 3E-H). The pathology seen in the retinas of BG1 recipients revealed minimal in filtrates and inflammation, even though the destruction of the retina ranged from limited loss of the $\mathrm{Bgal}^{+}$photoreceptor cells to substantial destruction of the retina. The infiltration of autoreactive $\mathrm{CD}^{+} \mathrm{T}$ cells was first seen in the $\beta$ gal-expressing photoreceptor cells (ONL and OS, Figure 3C). More severe disease progressed to loss of the photoreceptor cells (Figures 3E-G) with minimal recruitment of other inflammatory cells. Disease in some mice progressed to substantial loss of the retinal cells making up the inner and outer nuclear layers, and the RGC (Figure 3H).

\section{EXPRESSION OF $\beta$ GAL IN THE RETINA INHIBITS THE BG1 DTH RESPONSE}

Our previous studies showed that retinal Ag expression led to a reduction in the DTH response to that retinal Ag, whether the Ag-specific $\mathrm{T}$ cells were induced by immunization, adoptively transferred, or comprised the endogenous $\mathrm{T}$ cell repertoire in BgalTCR $\times$ B10.A-arrigal double Tg mice (Gregerson and Dou, 2002; Gregerson et al., 2008, 2009; McPherson et al., 2009). The $\mathrm{CD}^{+} \mathrm{T}$ cells in BG1 mice also mediated a DTH response to $\beta$ gal, and retinal $\beta$ gal expression in the double transgenic BG1 $\times$ arr $\beta$ gal mice led to inhibition of the DTH response to $\beta$ gal by the ear swelling assay (Figure 4). These results were consistent with previous experiments in the arrßgal mice showing that the inhibition of DTH in $\beta$ gal-immunized mice was mediated by $\mathrm{CD}^{+} 4^{+} 25^{+}$ T cells.

\section{ANTIGEN-SPECIFIC Foxp3 ${ }^{+}$TREGS MODULATE CD8 ${ }^{+}$T CELL $^{-}$ RESPONSES IN VIVO}

To determine if $\beta$ gal-specific Foxp3 ${ }^{+}$Tregs inhibit CD8 T cell mediated DTH in BG1 mice, Tregs were generated in Foxp3-GFP mice by i.v. administration of soluble $\beta$ gal or BSA (Thorstenson and Khoruts, 2001; Zhang et al., 2001). $\mathrm{GFP}^{+}$cells were isolated 8 days later by flow sorting for transfer to BG1 recipients. Little difference was found in the frequency of $\mathrm{GFP}^{+}$Tregs in $\mathrm{Ag}$ injected donor mice compared to non-injected controls (Figure 5A). Tregs from $\beta$ gal and BSA treated mice were transferred into naive BG1 mice and the DTH response to $\beta$ gal was analyzed. Mice that received BSA-induced Tregs had no reduction in ear swelling compared to normal BG1 mice, while mice receiving $\beta$ gal-induced Tregs showed a significant reduction in ear swelling (Figure 5B). Given that there was little, if any, difference in total Treg numbers between control and immunized mice, and that the 


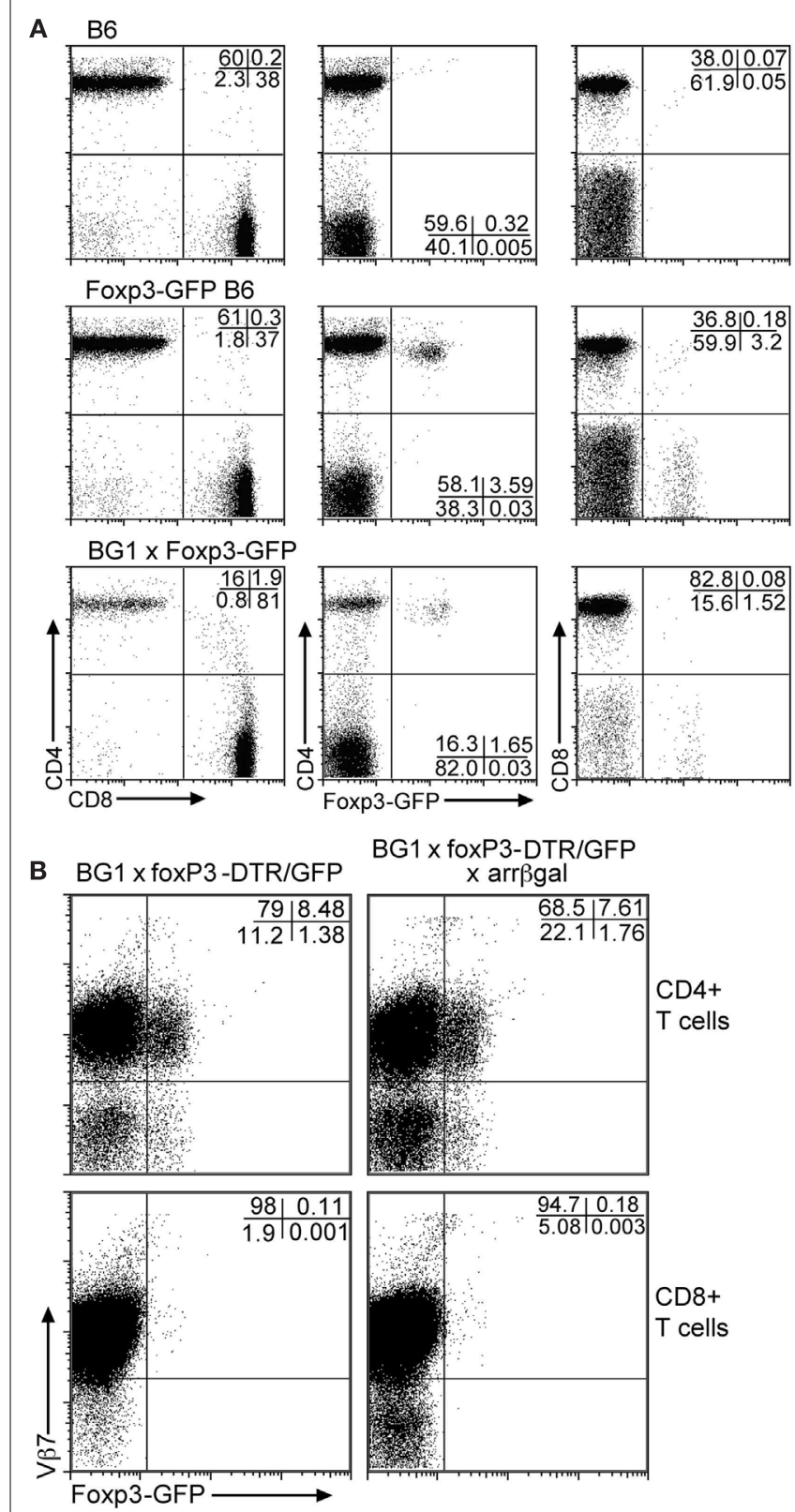

FIGURE 2 | Although the BG1 mice have a reduced population of CD4 T cells, the FoxP3-GFP ${ }^{+}$cells in BG1x Foxp3-DTR/GFP mice are concentrated in the CD4 population. (A) Comparison of Foxp3-GFP+ $T$ cells in PBL from mice with and without the TCR transgenes. (B) Association of the Foxp3-GFP+ Tregs with the $\mathrm{V} \beta 7^{+} \mathrm{CD} 4$ and $\mathrm{CD} 8 \mathrm{~T}$ cells. The distribution of Tregs in the $\mathrm{V} \beta 7^{+}$populations of $\mathrm{T}$ cells from peripheral blood was unaffected by retinal $\beta$ gal expression. Analyses were gated on $\mathrm{CD}^{+} \mathrm{T}$ cells. Representative plots are shown.
Tregs transferred contain both endogenous and Ag-specific Tregs induced by the i.v. $\beta$ gal, the results suggested that even a small number of $\beta$ gal-specific FoxP3 ${ }^{+}$Tregs have a significant effect on the systemic response of $\beta$ gal-specific $\mathrm{CD} 8^{+} \mathrm{T}$ cells.

In reciprocal experiments, we examined whether the removal of Tregs would enhance the DTH response in

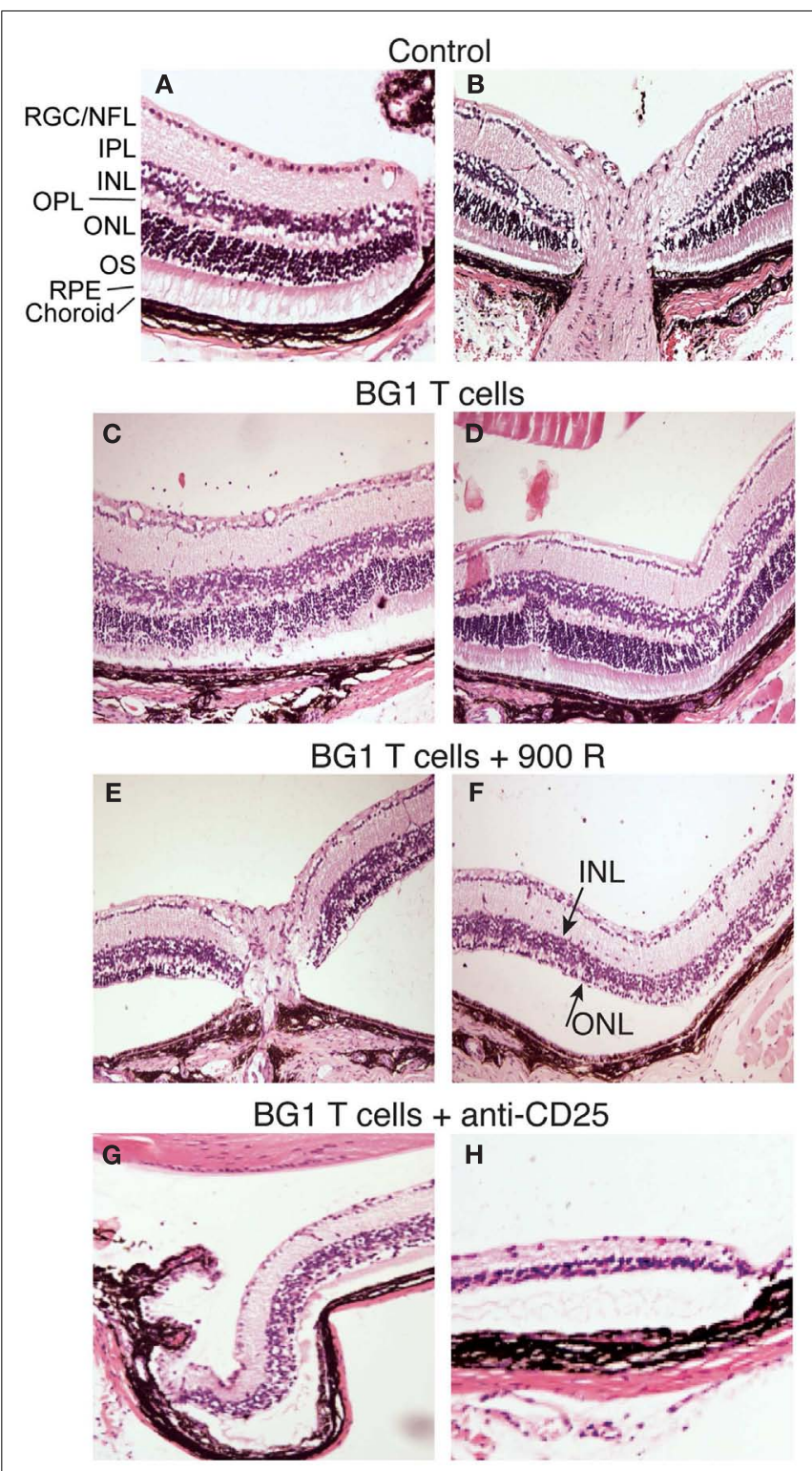

FIGURE 3 | Representative photomicrographs of autoimmune pathology in the eyes of arr $\beta$ gal mice induced by transfer of activated BG1 T cells. (A) Control retina, peripheral edge. (B) Control retina, optic nerve head. (C,D). Pathology in arr $\beta$ gal mice induced by peptide-activated BG1 T cells. Eyes harvested 21 days post-transfer. (E,F) Pathology induced in arr $\beta g a l$ mice by the transfer of activated BG1 T cells after conditioning with 900 R TBI. Eyes harvested 21 days post-transfer. (G,H). Pathology in the retinas of arrßgal mice that received anti-CD25 antibody prior to the transfer of activated BG1 T cells. Eyes harvested 25 days post-transfer. Abbreviations: RGC/NFL, retinal ganglion cell/nerve fiber layer; IPL, inner plexiform layer; INL, inner nuclear layer; OPL, outer plexiform layer; ONL, outer nuclear layer; OS, outer segments; RPE, retinal pigment epithelium.

BG1 $\times$ Foxp3-DTR/GFP double Tg mice. Tregs were substantially depleted by the i.p. administration of DTx. One day later, DTH was assayed by the ear swelling response to $\beta$ gal. Depleted BG1 $\times$ Foxp3-DTR/GFP double Tg mice had elevated levels of ear swelling compared to similarly treated BG1 mice and non-DTx 
Table 1 | Induction of EAU by adoptive transfer of activated BG1T cells was enhanced by lymphopenia or Treg depletion.

\begin{tabular}{|c|c|c|}
\hline \multirow[b]{2}{*}{$T_{\text {cells }}{ }^{1} /$ recipient $^{2}$} & \multicolumn{2}{|c|}{ Retinal pathology } \\
\hline & Incidence $^{3}$ & Severity ${ }^{4}$ \\
\hline $\mathrm{BG} 1^{-}$untreated & $2 / 18$ & $1.6 \pm 2.0$ \\
\hline $\mathrm{BG} 1+900 \mathrm{R}$ & $14 / 20^{5}$ & $1.8 \pm 1.4$ \\
\hline BG1 + anti-CD25 & $3 / 4^{5}$ & $4.3 \pm 1.2$ \\
\hline
\end{tabular}

BG1 T cells stimulated in vitro with DAPIYTNV.

${ }^{2}$ Arrßgal recipient mice were pretreated as shown.

${ }^{3}$ Number of mice with disease/total mice.

${ }^{4}$ Average score of diseased eyes only.

${ }^{5} p<0.05$ compared to BG1 T cells only.

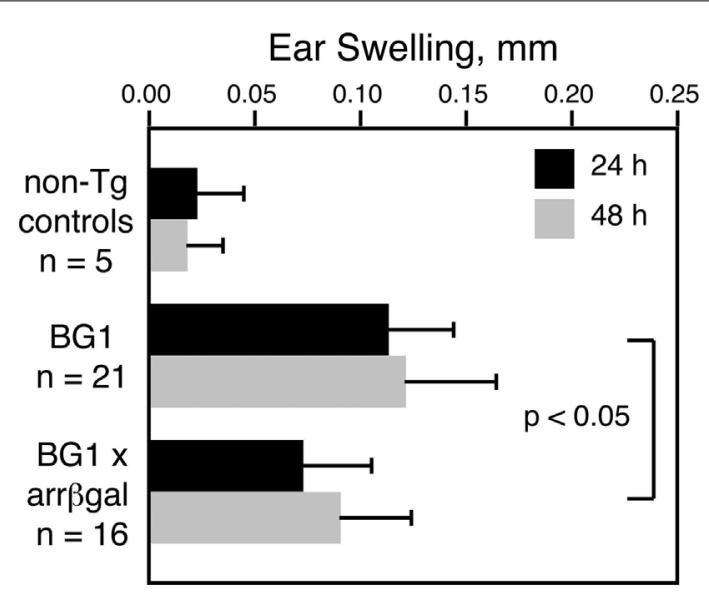

FIGURE 4 | Retinal expression of $\beta$ gal in the BG $1 \times$ arr $\beta$ gal mice leads to an inhibited DTH response to $\boldsymbol{\beta}$ gal. None of the mice were immunized; all were naive and unmanipulated. Ear swelling was induced as described in the Section "Materials and Methods." All results are given as mean $\pm \mathrm{SD}$ with $P$ values determined by $t$-test.

treated control mice (Figure 5C). Even in the absence of retinal $\beta$ gal expression as a transgene, there was still a sufficient number of Tregs to exert a detectable inhibition of the $\beta$ gal DTH response, and these Tregs were depleted by DTx, leading to increased ear swelling.

\section{TREGS SPECIFIC FOR RETINAL Ag ACT LOCALLY}

We recently described a DC population in the retina of CD11cDTR/GFP mice that could be eliminated from the retinal parenchyma by AC injection of as little as $1 \mathrm{ng}$ of DTx (Lehmann et al., 2010). To ensure delivery of an effective, local Treg-depleting dose of DTx, administration of $25 \mathrm{ng}$ of DTx into the AC of the eye was evaluated. The goal was to minimize systemic depletion of $\mathrm{DTR}^{+}$Tregs, but to ensure their depletion in retina. Tregs were depleted by i.p. delivery of DTx into Foxp3-DTR/GFP mice, but multiple injections of $25 \mathrm{ng}$ of DTx into the AC had no effect on Treg numbers in blood (Figure 6A). Analysis of the DTH response to $\beta$ gal showed no difference between right and left ears in mice that received right AC DTx injections, and that the response was
A

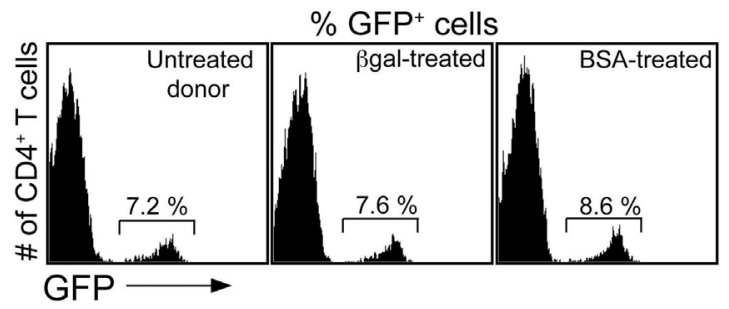

B

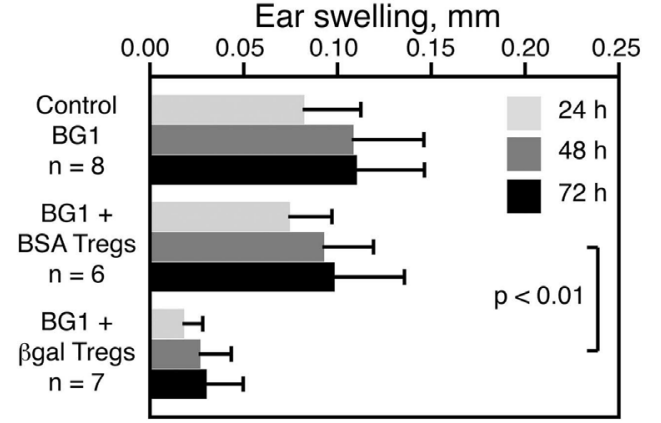

C

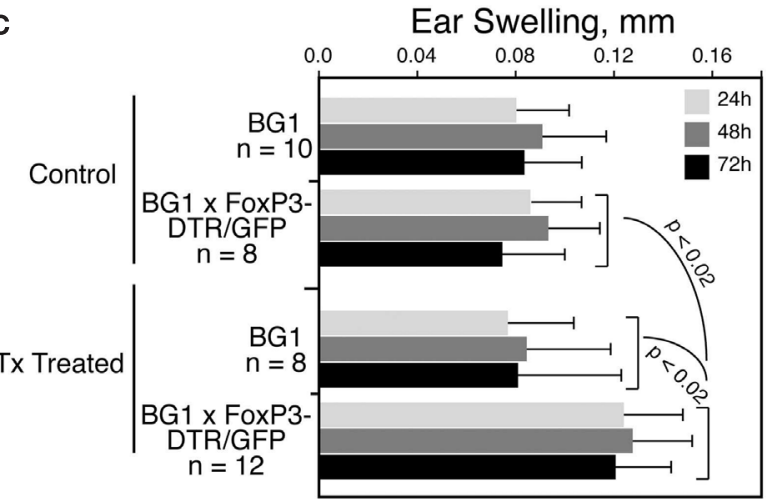

FIGURE 5 | $\beta$ gal-specific Tregs modulate the DTH response of $\beta$ gal-specific $\mathbf{C D 8}^{+} \mathbf{T}$ cells. (A) Flow cytometry of Tregs (CD4 ${ }^{+} \mathrm{GFP}+\mathrm{T}$ cells) in Foxp3-GFP mice following i.v. injection of $100 \mu \mathrm{g}$ BSA or $\beta$ gal. (B) Ear swelling assay in BG1 mice transferred with $5 \times 10^{5}$ total Tregs (GFP+ cells) from the BSA or $\beta$ gal-injected Foxp3-GFP mice shown in (A). Ear pinna injections with $\beta$ gal were done immediately after transfer of the GFP+

Tregs. (C) Depletion of Tregs by systemic DTx treatment increases the DTH response of $\mathrm{CD}_{4}{ }^{+}$and $\mathrm{CD} 8^{+} \mathrm{T}$ cells to $\beta \mathrm{gal}$. DTx $(250 \mathrm{ng} / \mathrm{injection})$ was given i.p. on days 0,3 , and 6 . $\beta$ gal was injected into the ear pinna on day 7 to start the DTH response. Ear swelling was read on days 8-10. Results are given as the mean \pm SD with $P$ values determined by $t$-test.

not significantly different than in mice without DTx treatment (data not shown).

Since the number of Foxp3-GFP ${ }^{+}$Tregs in the retinal parenchyma of quiescent BG1 mice was too small to detect, functional measures of Treg activity were used, and based on susceptibility to EAU. The consequences of local Treg depletion was tested by adoptive transfer of activated BG1 $\times$ Foxp3-DTR/GFP T cells into Foxp3-DTR/GFP $\times$ arrßgal mice (Figure 6B). The recipients received unilateral AC injections of $25 \mathrm{ng}$ DTx given three times per week to maintain local depletion of Foxp $3^{+}$Tregs. This strategy would effectively deplete Tregs whether they were derived from the existing recipient pool, or from donor-derived Tregs, or 


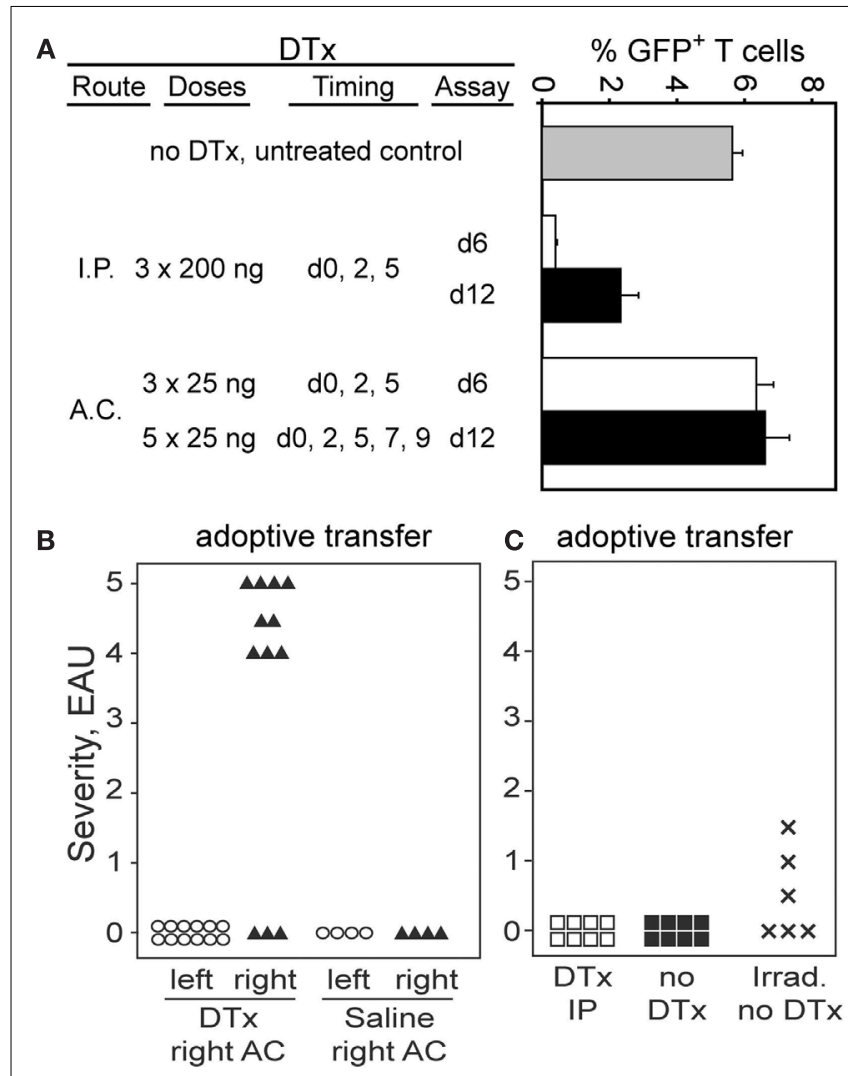

FIGURE 6 |Administration of DTx into the eye reveals that locally produced Tregs are responsible for protection of the retina from EAU.

(A) Administration of DTx to Foxp3-DTR/GFP mice by the AC route does not deplete Tregs systemically. Graph shows $\% \mathrm{GFP}^{+} \mathrm{T}$ cells in the fraction of $\mathrm{CD}^{+} 4^{+} \mathrm{T}$ cells in blood. (B) Transfer of activated BG1 $\times$ Foxp3-DTR/GFP T cells into Foxp3-DTR/GFP $\times$ arrßgal recipients, combined with local, unilateral depletion of Tregs leads to EAU in the depleted retina. Severe EAU was induced in retinas of eyes depleted of Tregs, but not in the contralateral retinas of the same animals. Control mice received an equal volume of saline in the AC. Mice were harvested 23 days post-transfer. Average EAU in all DTx treated eyes $=3.4 \pm 2.1$. (C) Systemic treatment with DTx did not promote EAU induction. Mice (Foxp3-DTR/GFP $\times$ arr $\beta$ gal) were treated with $250 \mathrm{ng}$ DTx on days 0,3 , and 6 . T cells from BG1 mice lacking the Foxp3-DTR transgene were activated with $\mathrm{Ag}$ in vitro, and $7.5 \times 10^{6} \mathrm{~T}$ cells transferred on day 7. Control mice were not DTx treated, or were given radiation to induce lymphopenia, which promotes pathogenesis of EAU. DTx treatment given i.p. reduced the frequency of GFP+ Tregs in blood from 3.6 to $0.4 \% 1$ day after the last treatment. were iTregs newly generated in the response to retinal $\beta$ gal. Mice that received activated T cells, but no DTx injections, had no evidence of EAU in their retinas (Figure 6B). Mice that received multiple, unilateral (right eye) AC injections of DTx developed severe EAU in the ipsilateral right eyes (9/12 eyes, severity $\geq 4$ ) but no EAU in the contralateral left eyes (Figure 6B). Unilateral injections of saline alone did not promote EAU induction (Figure 6B).

Controls for potential toxicity of DTx that was unrelated to expression of the DTR were done as follows. Since transfer of BG1 $\times$ Foxp3-DTR/GFP T cells gave a high incidence of severe EAU if the recipients were treated with DTx in the AC, the effect of the DTx on BG1 pathogenicity in the absence of the DTR was tested. If damage unrelated to Treg depletion by DTx was responsible for the EAU, then transfer with BG1 T cells lacking DTR should still give the severe EAU. Arr $\beta$ gal mice lacking the DTR transgene were transferred with activated BG1 T cells also lacking the DTR transgene. Treatment of these mice with the same dose, frequency, and AC route of DTx injection used in Figure 6B gave no EAU in any of 6 mice (data not shown). Further, treatment of $\operatorname{arr} \beta g a l \times$ Foxp3-DTR/GFP mice with the same toxin regimen, but without BG1 T cell transfer also gave no EAU in any of 8 DTX treated mice (data not shown).

To test the possibility that the transferred $\beta$ gal-specific $T$ cells are the source of the Tregs, a set of recipient mice with DTxsensitive Tregs (Foxp3-DTR/GFP $\times$ arr $\beta$ gal) was given systemic treatments of DTx, followed by transfer of activated BG1 T cells that lacked the DTR transgene. Multiple systemic treatments with DTx did not increase susceptibility to EAU by transfer of activated BG1 T cells that did not carry the Foxp3-DTR transgene. These results indicated that the transferred T cells were the source of the EAU-protective Tregs, as those cells were not sensitive to DTx. As a control, the same preparation of T cells produced EAU in recipients in which radiation was used to induce lymphopenia (Figure 6C), showing that they possessed pathogenicity in lymphopenic recipients. Although the number of DTx-sensitive Tregs in quiescent retina of Foxp3-DTR/GFP mice is too small to detect their elimination, use of DTx in other tissue sites in the Foxp3-DTR/GFP mice has been reported to deplete them effectively (Kim et al., 2007, 2009).

The difference between Treg activity generated locally and the activity of circulating, preformed Tregs was further examined by experiments in BG1 $\times$ Foxp3-DTR/GFP $\times$ arrßgal mice. Our hypothesis proposes that Tregs generated locally and acting locally protect the retina, and was supported by the experiments above. Administering DTx systemically allows testing of the role of preformed circulating Tregs. In these mice, the FoxP3 ${ }^{+}$Tregs are susceptible to DTx, and $\beta$ gal is present in the retina, providing the combination of potentially pathogenic $\mathrm{T}$ cells and target Ag. No spontaneous EAU has been observed in a large number of these mice. Mice given four doses of $500 \mathrm{ng}$ DTx/dose, at 4 days intervals failed to develop EAU, even though the systemic signs of autoimmunity associated with systemic depletion of Tregs appeared by the end of the 16-day course of the experiment (data not shown). Together, these results support the hypothesis that Tregs are generated in the retina, and inhibit EAU development.

\section{PATHOGENESIS OF EAU BY AUTOREACTIVE CD8 T CELLS DOES NOT REOUIRE RECRUITMENT OF MHC CLASS I+ CELLS TO THE RETINA}

The role of retinal APC in the pathogenesis of EAU mediated by CD8 $\mathrm{T}$ cells was examined by preparation of radiation $\mathrm{BM}$ chimeras whose MHC class I expression was manipulated. Prior to adoptive transfer of activated BG1 T cells, the recipient mice were conditioned by sublethal irradiation. Control experiments in which class $\mathrm{I}^{+}$BM was grafted into class $\mathrm{I}^{+}$recipients, yielded mice that were susceptible to EAU induction by the subsequent transfer of activated BG1 T cells (Group A, Figure 7, Top). Conversely, no EAU was found in control mice made with class $\mathrm{I}^{-1-}$ $\mathrm{BM}$ reconstitution of class $\mathrm{I}^{-1-}$ recipients, and transferred with 


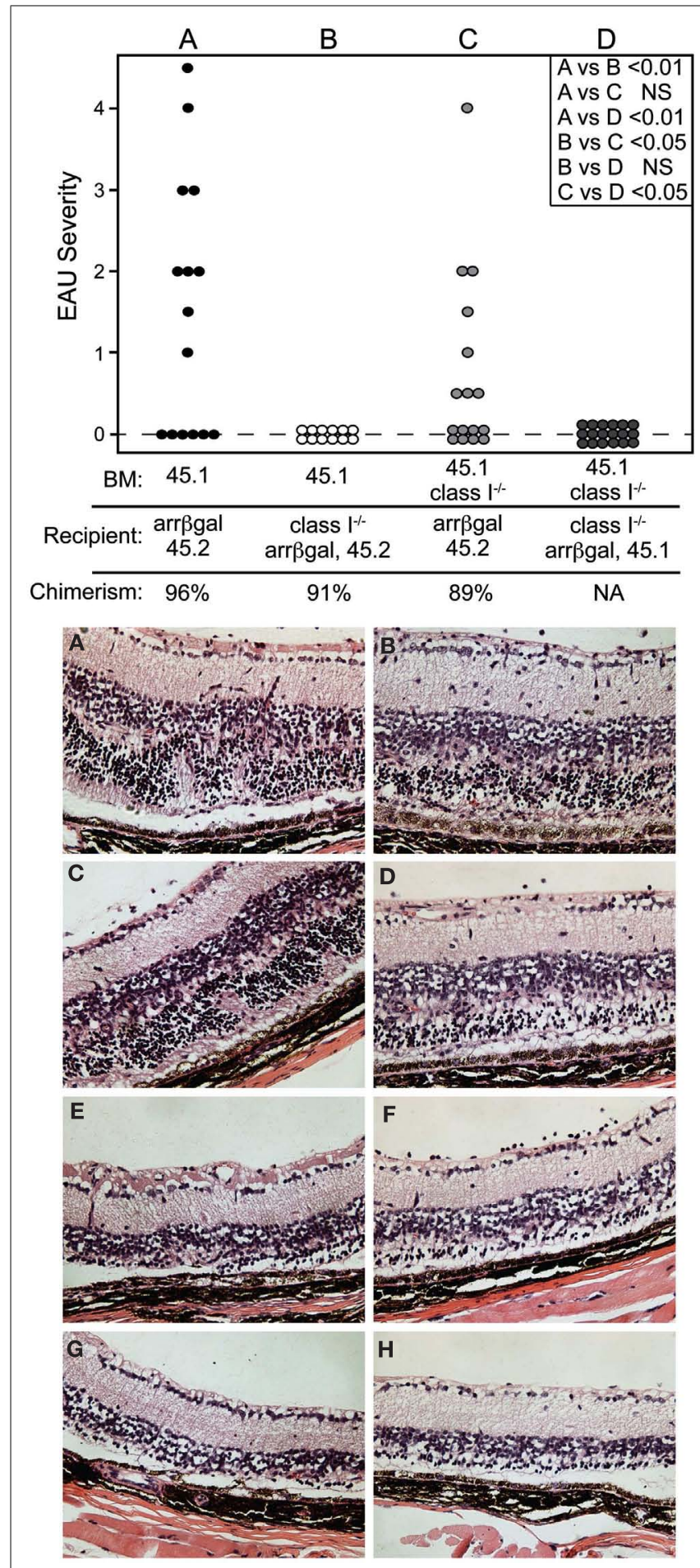

FIGURE 7 | Local expression of MHC class I is sufficient to support pathogenesis of CD8T cell mediated EAU. TOP. Chimeric mice made in recipients that were $\mathrm{MHC}$ class $\mathrm{I}^{+}$, but whose non-resident retinal immune cells were replaced by grafting class I-BM (group C) were susceptible to EAU by adoptive transfer of activated BG1 T cells. Conversely, recipient mice that were class $\mathrm{I}^{-}$, but given class $\mathrm{I}^{+} \mathrm{BM}$ (group B) were resistant to EAU. Control groups $A$ and $D$ were subjected to the chimerism procedures, but were fully class $\mathrm{I}^{+}$or class $\mathrm{I}^{-}$, respectively. Recipients were sublethally

(Continued)

\section{FIGURE 7 | Continued}

irradiated prior to transfer of the BG1 cells to induce the lymphopenia that promotes EAU induction. INSET. Comparisons of all eyes were made using non-parametric $P$ values determined by Kruskal-Wallis test. Comparison of the severity in only the EAU-positive eyes (normally distributed) in groups A vs. $C$ was also done by a $t$-test, and showed a $P$ value of $<0.05$. BOTTOM. Histopathology of retinas from group A (A-D) and group $C(\mathbf{E}-\mathbf{H})$ showed that the presence or absence of class $\mathrm{I}^{+}$cells in the circulation had little effect on the cellularity of the inflammation and pathogenesis of CD8T cell mediated EAU. All mice expressed retinal $\beta$ gal.

the activated BG1 T cells (Group D, Figure 7, Top). No EAU was found in class $\mathrm{I}^{-1-}$ recipients of wt BM transferred with activated BG1 T cells, suggesting that the $\beta_{g a l}{ }^{+}$photoreceptor cells do not express a sufficient level of MHC class I to support direct cytotoxic killing by the BG1 T cells (Group B, Figure 7, Top). It also suggests that the resident, class $\mathrm{I}^{-1-}$ microglia in these retina, which turnover slowly in the absence of a stimulus, were not replaced by class $\mathrm{I}^{+}$donor cells during the 19 -week period post-grafting to a level that supported pathogenesis based on class I expression by the donor-derived microglia. Class $\mathrm{I}^{+}$recipient mice receiving class $\mathrm{I}^{-1-}$ BM developed were clearly susceptible to EAU (Group C, Figure 7 Top), but the severity in the EAU-positive eyes only was less than found in the Group A controls. The outcomes in Groups A and $\mathrm{C}$ were consistent with local Ag presentation supporting EAU that could be augmented by class $\mathrm{I}^{+}$recruited cells, and strengthened our recent results demonstrating the significance of local Ag presentation in EAU (Heuss et al., 2012). The histopathology found in groups A and C was similar (Figure 7, Bottom). In all cases, there was minimal inflammatory infiltrate that was not significantly altered by the class I expression of the circulating cells available for recruitment.

\section{DISCUSSION}

With the exception of IRBP-induced CD4 T cell mediated EAU in the B10.R3 strain, mice are relatively resistant to retinal autoimmune inflammation (Caspi et al., 1992; Silver et al., 1995; Sun et al., 1997). A role for Tregs in that resistance has been described. For example, thymic expression of retinal IRBP resulting from aire gene activity, leads to thymic production of natural Tregs (nTregs) that suppress retinal autoimmunity (DeVoss et al., 2006). The presence or absence of thymic IRBP affected EAU susceptibility and systemic IRBP responses (Avichezer et al., 2003a,b). Expression of several immunopathogenic retinal autoAgs has been found in rodent and human thymus (Egwuagu et al., 1997; Gery and Egwuagu, 2002; Takase et al., 2005). Together, these findings support central tolerance as an important mechanism that contributes to retinal immune privilege. Our studies asked if Tregs are a factor in the resistance of murine retina to autoimmune disease directed to other retinal $\mathrm{Ag}$, particularly in the context of pathogenic, autoreactive CD8 T cells.

Study of the control of CD8 T cell mediated autoimmunity by Foxp $3^{+}$Tregs has received much less attention than autoimmune diseases mediated by CD4 T cells. Using viral CNS infection of mice with DTx-sensitive Tregs, the recruitment of CD8 T cells specific for known epitopes of the virus was unaffected by depletion of the Tregs (Cervantes-Barragan et al., 2012). In contrast, 
the frequency of CD8 T cells specific for bystander epitopes was increased by the Treg depletion, leading to the hypothesis that Tregs in viral CNS inflammation largely serve to protect from self-reactive $\mathrm{T}$ cells, while allowing the anti-viral response to progress, protecting the CNS. In a model incorporating CD8 T cells specific for influenza hemagglutinin $\mathrm{Ag}$, and lung expression of hemagglutinin, the evidence was consistent with Tregs exerting some control of self-reactive T cells, but the contribution of unknown mechanisms appeared to be dominant in preventing autoimmune inflammation (Tosiek et al., 2011).

Published and preliminary results from our lab show that retinal expression of the neo-self-Ag, $\beta$ gal, promoted the generation of functionally significant $\beta$ gal-specific Tregs from naive $\beta$ galspecific $\mathrm{T}$ cells transferred into $\mathrm{Rag}^{-1-}$ mice expressing $\beta$ gal in retina (Gregerson et al., 2008, 2009; McPherson et al., 2009; Heuss et al., 2012). iTregs are known to be generated in the periphery from mature $\mathrm{T}$ cells upon encounter with self and foreign $\mathrm{Ag}$, under conditions that promote iTreg differentiation, including the presence of retinoic acid and TGF $\beta$ (Chen et al., 2003; Hall et al., 2011). In many cases the Treg-generating interactions take place in lymphoid tissues, especially LNs (del Rio et al., 2010). In light of these results, we proposed that the resistance of arrßgal mice to EAU is due to an efficient ongoing generation of iTregs from the mature, peripheral population of $\beta$ gal-specific $\mathrm{T}$ cells, and sought evidence for their local activity in protecting from EAU.

We reported that quiescent retina of normal B6 mice contains a small number of $\alpha / \beta \mathrm{T}$ cells, approximately $40-50$ per retina, and that approximately $5 \%$ of these $\left(2 /\right.$ retina) were Foxp $3^{+}$, based on their GFP expression in Foxp3-DTR/GFP mice (Heuss et al., 2012). The retina of the BG1 $\times$ Foxp3-DTR/GFP mice was similarly populated with $\mathrm{T}$ cells, including $\mathrm{GFP}^{+}$Tregs. Their specificity is unknown, but it seems improbable that this small number could block the challenge posed by transfer of several million activated CD8 $\mathrm{T}$ cells with specificity for a retinal antigen, as we have shown here. The experiments showing the role of retinal DC in the generation of Foxp $3^{+}$Tregs (Heuss et al., 2012), and the data presented here showing that local depletion of Tregs allows development of EAU, points to the hypothesis that local Tregs provide the dynamic, effective resistance to CD8 T cell mediated EAU that has been found in the arrßgal mice. We suggest that this is a basic mechanism that is the foundation of the steady-state control of the susceptibility of the retina to autoimmune disease. Since this mechanism rapidly provides Tregs as needed, it lessens concerns for the lack of long-term stability in the iTreg population (Floess et al., 2007; Selvaraj and Geiger, 2007), or holes in the repertoire of specificities in the nTreg population. One could argue that the generation of the retina-protective Treg population we have described was an unusual phenomena limited to the high TGF $\beta$ and retinoic acid environment of the retina. However, retina, mucosal tissue, and brain share the characteristic of locales rich in TGF $\beta$ and retinoic acid (Chen et al., 2003; Coombes et al., 2007; Apostolou et al., 2008; Zhou et al., 2011). This feature may be found to be more widespread than previously thought.

The speed at which retinal protective Tregs were produced may be key to their effectiveness, as they appeared in the retina within 2 days of local antigen exposure in the retina (Heuss et al., 2012). Some studies using non-tissue-specific autoantigens identified LNs as a site of Treg generation and function. The Treg populations in those studies appear to require a sequential migratory pattern that includes transport through the vasculature to an inflamed tissue site, followed by emigration via the afferent lymphatic to draining LN where they acquire regulatory function (Zhang et al., 2009). From there, they are deployed in LN, where they inhibit recruitment and expansion of effector T cells, and also return to the site of inflammation where they provide local suppression (Suri-Payer et al., 1998; Huehn and Hamann, 2005). This rather lengthy process is unlikely to provide the rapid appearance of Tregs we found after 2 days in a site that is not inflamed, and lacks lymphatic drainage. Local regulatory activity has been found in the inflamed CNS using the EAE model (O'Connor et al., 2007). In unpublished experiments we have not found that DTx treatment of local LN impairs the Treg protection of retina.

We propose that the small number of Tregs present in quiescent retina were not a barrier to pathogenic T cells and EAU. The volume of the retina and the extensive vasculature would be a prohibitively large area for those few Tregs to peruse for invading $\mathrm{T}$ cells. However, local Treg depletion allowed the adoptive transfer model of EAU to produce a high incidence of severe EAU limited to the ipsilateral retina. Although LN that drain some ocular structures have been demonstrated (Camelo et al., 2006), the retina has not been demonstrated to be a tissue with lymphatic drainage. Tregs are not known to migrate anterograde from $\mathrm{LN}$, through the lymphatics, to reach the retina or surrounding tissues. These results and considerations support our hypothesis that Tregs in the retina may be made locally, on demand. Their activity was clearly a dominant factor in retinal immune homeostasis, as their local depletion was permissive for destructive EAU. The appearance of Tregs in the retina upon local challenge is dependent on either the direct recruitment of Tregs from the circulation, or on their development from $\mathrm{T}$ cells recruited into the retina. If so, their rapid local production may be critical in providing regulation early in the response before pathogenesis begins, thus warding off disease onset at a time when the conditions are more manageable. The role of pre-existing, circulating Tregs has been more difficult to evaluate, since sustained, systemic depletion of Tregs in the Foxp3-DTR/GFP mice leads to progressive, lethal systemic autoimmunity (Kim et al., 2009). Several preliminary trials testing the effect of systemic depletion of Tregs in the Foxp3-DTR/GFP mice by DTx administration, with and without the $\beta$ gal transgene in the retina or the BG1 TCR transgenes, failed to produce evidence of inflammation or damage to the retina. Although these trials were terminated at the first clear signs of stress, they did not produce results that would suggest that preformed Tregs were protecting the retina from autoimmunity. The existing nTregs may lack specificity for a local retinal Ag, or access to the retina, marginalizing their function in EAU. We interpret these results as supporting our hypothesis that the Tregs that protect the retina, as demonstrated in Figure 6, may be made locally and when needed.

Concerns for non-specific damage due to DTx-mediated injury of murine cells not targeted to express the primate DTR have 
been raised. Although evidence for such damage has not been substantiated by experimentation in other experimental models (Kim et al., 2009), the possibility of toxicity was tested here. In our studies of the retina, multiple injections of $25 \mathrm{ng}$ DTx into the $\mathrm{AC}$ of $\mathrm{C} 57 \mathrm{BL} / 6 \mathrm{~J}$ control mice did not induce damage that could be distinguished from similar injections of saline alone. In conventional adoptive transfer experiments in which neither the activated BG1 T cells nor the arr $\beta$ gal recipients expressed the DTR, no promotion of EAU was found. Control experiments for the injury due to repeated AC injections, separate from DTX toxicity, found that saline injections into the AC did not promote EAU induction in mice following adoptive transfer of activated BG1 T cells. Only local AC injection of DTx gave EAU in the ipsilateral retinas, confirming the local DTx dependency of the EAU.

The data presented here suggest several questions for future experiments. Is the function of the Tregs that protect retina proactive or reactive? Their numbers seem too sparse to be protective in a proactive manner, but if injury or other stimulus led to their rapid generation in the retina, where the target Ag was located, they might be able to alter the activity of the pathogenic T cells as they entered. If they are generated reactively, as part of the influx of pathogenic $\mathrm{T}$ cells, are they long-lived or do they act in the

\section{REFERENCES}

Apostolou, I., Verginis, P., Kretschmer, K., Polansky, J., Huhn, J., and Von Boehmer, H. (2008). Peripherally induced Treg: mode, stability, and role in specific tolerance. J. Clin. Immunol. 28, 619-624.

Avichezer, D., Grajewski, R. S., Chan, C. C., Mattapallil, M. J., Silver, P. B., Raber, J. A., Liou, G. I., Wiggert, B., Lewis, G. M., Donoso, L. A., and Caspi, R. R. (2003a). An immunologically privileged retinal antigen elicits tolerance: major role for central selection mechanisms. J. Exp. Med. 198, 1665-1676.

Avichezer, D., Liou, G. I., Chan, C. C., Lewis, G. M., Wiggert, B., Donoso, L. A., Nickerson, J. M., Crawford, M. A., and Caspi, R. R. (2003b). Interphotoreceptor retinoid-binding protein (IRBP)-deficient C57BL/6 mice have enhanced immunological and immunopathogenic responses to IRBP and an altered recognition of IRBP epitopes. J. Autoimmun. 21, 185-194.

Camelo, S., Kezic, J., Shanley, A., Rigby, P., and McMenamin, P. G. (2006). Antigen from the anterior chamber of the eye travels in a soluble form to secondary lymphoid organs via lymphatic and vascular routes. Invest. Ophthalmol. Vis. Sci. 47, 1039-1046.

Carson, M. J., Doose, J. M., Melchior, B., Schmid, C. D., and Ploix, C. C. (2006). CNS immune privilege: hiding in plain sight. Immunol. Rev. 213, 48-65.

Caspi, R. (2008). Autoimmunity in the immune privileged eye: pathogenic and regulatory T cells. Immunol. Res. 42, 41-50.

Caspi, R. R. (2006). Ocular autoimmunity: the price of privilege? Immunol. Rev. 213, 23-35.

Caspi, R. R., Grubbs, B. G., Chan, C. C., Chader, G. J., and Wiggert, B. (1992). Genetic control of susceptibility to experimental autoimmune uveoretinitis in the mouse model. Concomitant regulation by $\mathrm{MHC}$ and non-MHC genes. J. Immunol. 148, 2384-2389.

Cervantes-Barragan, L., Firner, S., Bechwasser, T., Thiel, V., and Ludewig, B. (2012). Regulatory T cells selectively preserve immune privilege of selfantigens during viral central nervous system infection. J. Immunol. 188, 3678-3685.

Chen, W., Jin, W., Hardegen, N., Lei, K. J., Li, L., Marinos, N., McGrady, G., and Wahl, S. M. (2003). Conversion of peripheral CD4+ CD25naive $\mathrm{T}$ cells to $\mathrm{CD} 4+\mathrm{CD} 25+$ regulatory $\mathrm{T}$ cells by TGF-beta induction of transcription factor Foxp3. J. Exp. Med. 198, 1875-1886.

Coombes, J. L., Siddiqui, K. R., Arancibia-Carcamo, C. V., Hall, J., Sun, C. M., Belkaid, Y., and Powrie, F. (2007). A functionally specialized population of mucosal CD103+ mann, I., Waisman, A., Lahl, K., SparDCs induces Foxp3+ regulatory $\mathrm{T}$

short term to protect only while the tissue is challenged with pathogenic T cells? The derivation of the Tregs is uncertain; although they appear to act locally, based on the depletion studies, where do they originate? Are they derived from naive cells, or from the infiltrating, activated $\mathrm{T}$ cells with specificity for a local, retinal antigen?

In the model we have described, the frequency of $\mathrm{CD} 8^{+} \mathrm{Foxp}^{+}$ $\mathrm{T}$ cells is only $0.1 \%$ of the $\mathrm{CD} 8 \mathrm{~T}$ cells, whereas the $\mathrm{CD} 4^{+} \mathrm{Foxp}^{+}$ Tregs are approximately $9 \%$ of the $\mathrm{CD} 4 \mathrm{~T}$ cells. The $\mathrm{CD} 8^{+} \mathrm{V} \beta 7^{+}$ $\mathrm{T}$ cells are the only cells in these mice with known specificity for the class I-restricted $\beta$ gal peptide. Although a number of $\mathrm{CD}^{+}$Treg subsets have been described (Tsai et al., 2011), only the Foxp $3^{+}$-DTR/GFP ${ }^{+}$subset can be the immediate precursors for the DTx-sensitive cells with Treg activity in our study. Further studies will be needed to determine the phenotype and specificity of the DTx-sensitive Tregs.

\section{ACKNOWLEDGMENTS}

We thank Heidi Roehrich for histology and Mark Pierson for technical assistance. This work was supported by NIH research grants R01-EY011542, R01-EY016376, and core facilities grant P30-EY011374. Additional support was provided by Research to Prevent Blindness, Inc., and the Minnesota Lions Clubs.

cells via a TGF-beta and retinoic acid-dependent mechanism. J. Exp. Med. 204, 1757-1764.

Cserr, H. F., Harling-Berg, C. J., and Knopf, P. M. (1992). Drainage of brain extracellular fluid into blood and deep cervical lymph and its immunological significance. Brain Pathol. 2, 269-276.

Curotto de Lafaille, M. A., Lino, A. C., Kutchukhidze, N., and Lafaille, J. J. (2004). CD25- T cells generate CD25+ Foxp3+ regulatory $\mathrm{T}$ cells by peripheral expansion. J. Immunol. 173, 7259-7268.

del Rio, M. L., Bernhardt, G., RodriguezBarbosa, J. I., and Forster, R. (2010). Development and functional specialization of $\mathrm{CD} 103+$ dendritic cells. Immunol. Rev. 234, 268-281.

DeVoss, J., Hou, Y., Johannes, K., Lu, W. Liou, G. I., Rinn, J., Chang, H., Caspi, R., Fong, L., and Anderson, M. S. (2006). Spontaneous autoimmunity prevented by thymic expression of a single self-antigen. J. Exp. Med. 203, 2727-2735.

DiPaolo, R. J., Brinster, C., Davidson, T. S., Andersson, J., Glass, D., and Shevach, E. M. (2007). Autoantigenspecific TGF beta-induced Foxp3+ regulatory $\mathrm{T}$ cells prevent autoimmunity by inhibiting dendritic cells from activating autoreactive $\mathrm{T}$ cells. J. Immunol. 179 , 4685-4693.

Donohue, K. B., Grant, J. M., Tewalt, E. F., Palmer, D. C., Theoret, M. R.,
Restifo, N. P., and Norbury, C. C. (2006). Cross-priming utilizes antigen not available to the direct presentation pathway. Immunology 119 , 63-73.

Egwuagu, C. E., Charukamnoetkanok, P., and Gery, I. (1997). Thymic expression of autoantigens correlates with resistance to autoimmune disease. J. Immunol. 159, 3109-3112.

Floess, S., Freyer, J., Siewert, C., Baron, U., Olek, S., Polansky, J., Schlawe, K., Chang, H. D., Bopp, T., Schmitt, E., Klein-Hessling, S., Serfling, E., Hamann, A., and Huehn, J. (2007). Epigenetic control of the foxp3 locus in regulatory T cells. PLoS Biol. 5, e38. doi:10.1371/journal.pbio.0050038

Fontenot, J. D., Rasmussen, J. P., Williams, L. M., Dooley, J. L., Farr, A. G., and Rudensky, A. Y. (2005). Regulatory $\mathrm{T}$ cell lineage specification by the forkhead transcription factor foxp3. Immunity 22, 329-341.

Gery, I., and Egwuagu, C. E. (2002). Central tolerance mechanisms in control of susceptibility to autoimmune uveitic disease. Int. Rev. Immunol. 21, 89-100.

Grajewski, R. S., Silver, P. B., Agarwal, R. K., Su, S. B., Chan, C. C., Liou, G. I., and Caspi, R. R. (2006). Endogenous IRBP can be dispensable for generation of natural $\mathrm{CD} 4+\mathrm{CD} 25+$ regulatory $\mathrm{T}$ cells that protect from IRBP-induced retinal autoimmunity. J. Exp. Med. 203 , $851-856$. 
Gregerson, D. S. (1998). Immune privilege in the retina. Ocul. Immunol. Inflamm. 6, 257-267.

Gregerson, D. S. (2002). Peripheral expression of ocular antigens in regulation and therapy of ocular autoimmunity. Int. Rev. Immunol. 21, 101-121.

Gregerson, D. S., and Dou, C. (2002). Spontaneous induction of immunoregulation by an endogenous retinal antigen. Invest. Ophthalmol. Vis. Sci. 43, 2984-2991.

Gregerson, D. S., Heuss, N. D., Lehmann, U., and McPherson, S. W. (2008). Evidence for extrathymic generation of regulatory $\mathrm{T}$ cells specific for a retinal antigen. Ophthalmic Res. 40, 154-159.

Gregerson, D. S., Heuss, N. D., Lehmann, U., and Mcpherson, S. W. (2009). Peripheral induction of tolerance by retinal antigen expression. J. Immunol. 183, 814-822.

Gregerson, D. S., Obritsch, W. F., and Donoso, L. A. (1993). Oral tolerance in experimental autoimmune uveoretinitis. Distinct mechanisms of resistance are induced by low dose vs. high dose feeding protocols. J. Immunol. 151, 5751-5761.

Gregerson, D. S., Obritsch, W. F., Fling, S. P., and Cameron, J. D. (1986). S-antigen-specific rat T cell lines recognize peptide fragments of S-antigen and mediate experimental autoimmune uveoretinitis and pinealitis. J. Immunol. 136, 2875-2882.

Gregerson, D. S., Torseth, J. W., McPherson, S. W., Roberts, J. P., Shinohara, T., and Zack, D. J. (1999). Retinal expression of a neo-self antigen, beta-galactosidase, is not tolerogenic and creates a target for autoimmune uveoretinitis. J. Immunol. 163, 1073-1080.

Hall, J. A., Grainger, J. R., Spencer, S. P., and Belkaid, Y. (2011). The role of retinoic acid in tolerance and immunity. Immunity 35, 13-22.

Ham, D. I., Kim, S. J., Chen, J., Vistica, B. P., Fariss, R. N., Lee, R. S., Wawrousek, E. F., Takase, H., Yu, C. R., Egwuagu, C. E., Chan, C. C., and Gery, I. (2004). Central immunotolerance in transgenic mice expressing a foreign antigen under control of the rhodopsin promoter. Invest. Ophthalmol. Vis. Sci. 45, 857-862.

Heuss, N. D., Lehmann, U., Norbury, C. C., Mcpherson, S. W., and Gregerson, D. S. (2012). Local activation of dendritic cells alters the pathogenesis of autoimmune disease in the retina. J. Immunol. 188 , 1191-1200.
Hori, J., Vega, J. L., and Masli, S. (2010). Review of ocular immune privilege in the year 2010: modifying the immune privilege of the eye. Ocul. Immunol. Inflamm. 18, 325-333.

Huehn, J., and Hamann, A. (2005). Homing to suppress: address codes for Treg migration. Trends Immunol. 26, 632-636.

Jutel, M., and Akdis, C. A. (2008). T-cell regulatory mechanisms in specific immunotherapy. Chem. Immunol. Allergy 94, 158-177.

Kim, J., Lahl, K., Hori, S., Loddenkemper, C., Chaudhry, A., Deroos, P., Rudensky, A., and Sparwasser, T. (2009). Cutting edge: depletion of Foxp3+ cells leads to induction of autoimmunity by specific ablation of regulatory $\mathrm{T}$ cells in genetically targeted mice. J. Immunol. 183, 7631-7634.

Kim, J. M., Rasmussen, J. P., and Rudensky, A. Y. (2007). Regulatory T cells prevent catastrophic autoimmunity throughout the lifespan of mice. Nat. Immunol. 8, 191-197.

Lambe, T., Leung, J. C., Ferry, H., Bouriez-Jones, T., Makinen, K., Crockford, T. L., Jiang, H. R., Nickerson, J. M., Peltonen, L., Forrester, J. V., and Cornall, R. J. (2007). Limited peripheral $\mathrm{T}$ cell anergy predisposes to retinal autoimmunity. J. Immunol. 178, 4276-4283.

Lehmann, U., Heuss, N. D., McPherson, S. W., Roehrich, H., and Gregerson, D. S. (2010). Dendritic cells are early responders to retinal injury. Neurobiol. Dis. 40, 177-184.

Lohr, J., Knoechel, B., and Abbas, A. K. (2006). Regulatory $T$ cells in the periphery. Immunol. Rev. 212, 149-162.

McPherson, S. W., and Gregerson, D. S. (1994). "Nucleotide sequences homologous to retinal S-antigen in the rat thymus lack a known EAU inducing epitope," in Sixth International Symposium on the Immunology and Immunopathology of the Eye, eds R. B. Nussenblatt, S. M. Whitcup, R. R. Caspi, and I. Gery (Amsterdam: Elsevier Sciences B.V.), 67-70.

McPherson, S. W., Heuss, N. D., and Gregerson, D. S. (2009). Lymphopenia-induced proliferation is a potent activator for $\mathrm{CD} 4+\mathrm{T}$ cellmediated autoimmune disease in the retina. J. Immunol. 182, 969-979.

McPherson, S. W., Heuss, N. D., Roehrich, H., and Gregerson, D. S. (2006). Bystander killing of neurons by cytotoxic $\mathrm{T}$ cells specific for a glial antigen. Glia 53, 457-466.

McPherson, S. W., Yang, J., Chan, C. C., Dou, C., and Gregerson, D. S. (2003). Resting CD8 T cells recognize beta-galactosidase expressed in the immune-privileged retina and mediate autoimmune disease when activated. Immunology 110, 386-396.

Niederkorn, J. Y. (2007). Regulatory T cells and the eye. Chem. Immunol. Allergy 92, 131-139.

Niederkorn, J. Y., and Wang, S. (2005). Immune privilege of the eye and fetus: parallel universes? Transplantation 80, 1139-1144.

O'Connor, R. A., Malpass, K. H., and Anderton, S. M. (2007). The inflamed central nervous system drives the activation and rapid proliferation of Foxp3+ regulatory T cells. J. Immunol. 179, 958-966.

Rizzo, L. V., Silver, P., Wiggert, B. Hakim, F., Gazzinelli, R. T., Chan, C.-C., and Caspi, R. R. (1996). Establishment and characterization of a murine CD4+ T cell line and clone that induce experimental autoimmune uveoretinitis in B10.A mice. $J$. Immunol. 156, 1654-1660.

Sakaguchi, S. (2011). Regulatory T cells: history and perspective. Methods Mol. Biol. 707, 3-17.

Selvaraj, R. K., and Geiger, T. L. (2007). A kinetic and dynamic analysis of Foxp3 induced in $\mathrm{T}$ cells by TGFbeta. J. Immunol. 178, 7667-7677.

Shevach, E. M., Dipaolo, R. A., Andersson, J., Zhao, D. M., Stephens, G. L., and Thornton, A. M. (2006). The lifestyle of naturally occurring CD4+ CD25+ Foxp3+ regulatory T cells. Immunol. Rev. 212, 60-73.

Silver, P. B., Agarwal, R. K., Su, S. B., Suffia, I., Grajewski, R. S., Luger, D., Chan, C. C., Mahdi, R. M., Nickerson, J. M., and Caspi, R. R. (2007). Hydrodynamic vaccination with DNA encoding an immunologically privileged retinal antigen protects from autoimmunity through induction of regulatory $\mathrm{T}$ cells. $J$. Immunol. 179, 5146-5158.

Silver, P. B., Rizzo, L. V., Chan, C. C., Donoso, L. A., Wiggert, B., and Caspi, R. R. (1995). Identification of a major pathogenic epitope in the human IRBP molecule recognized by mice of the H-2r haplotype. Invest. Ophthalmol. Vis. Sci. 36, 946-954.

Song, L., Le, J., Ye, F., Shao, H., Kaplan, H. J., and Sun, D. (2008). Sequence 168 to 177 of interphotoreceptor retinoid-binding protein (IRBP) is an antigenic epitope for autoreactive CD8 T cells in the B10RIII mouse. $J$. Neuroimmunol. 193, 68-76.

Stein-Streilein, J., and Taylor, A. W. (2007). An eye's view of T regulatory cells. J. Leukoc. Biol. 81, 593-598.
Streilein, J. W. (2003). Ocular immune privilege: the eye takes a dim but practical view of immunity and inflammation. J. Leukoc. Biol. 74 179-185.

Su, S. B., Silver, P. B., Zhang, M., Chan, C. C., and Caspi, R. R. (2001). Pertussis toxin inhibits induction of tissuespecific autoimmune disease by disrupting $\mathrm{G}$ protein-coupled signals. J. Immunol. 167, 250-256.

Sun, B., Rizzo, L. V., Sun, S. H., Chan, C. C., Wiggert, B., Wilder, R. L., and Caspi, R. R. (1997). Genetic susceptibility to experimental autoimmune uveitis involves more than a predisposition to generate a $\mathrm{T}$ helper-1like or a $\mathrm{T}$ helper-2-like response. $J$. Immunol. 159, 1004-1011.

Suri-Payer, E., Amar, A. Z., Thornton, A. M., and Shevach, E. M. (1998). CD4+CD25+ T cells inhibit both the induction and effector function of autoreactive $\mathrm{T}$ cells and represent a unique lineage of immunoregulatory cells. J. Immunol. 160, 1212-1218.

Takase, H., Yu, C. R., Mahdi, R. M., Douek, D. C., Dirusso, G. B., Midgley, F. M., Dogra, R., Allende, G., Rosenkranz, E., Pugliese, A., Egwuagu, C. E., and Gery, I. (2005). Thymic expression of peripheral tissue antigens in humans: a remarkable variability among individuals. Int. Immunol. 17 1131-1140.

Taylor, A. W. (2009). Ocular immune privilege. Eye (Lond.) 23, 1885-1889.

Tewalt, E. F., Grant, J. M., Granger, E. L., Palmer, D. C., Heuss, N. D., Gregerson, D. S., Restifo, N P., and Norbury, C. C. (2009). Viral sequestration of antigen subverts cross presentation to $\mathrm{CD} 8(+)$ T cells. PLoS Pathog. 5, e1000457. doi:10.1371/journal.ppat.1000457

Thorstenson, K. M., and Khoruts, A. (2001). Generation of anergic and potentially immunoregulatory $\mathrm{CD} 25+\mathrm{CD} 4 \mathrm{~T}$ cells in vivo after induction of peripheral tolerance with intravenous or oral antigen. $J$. Immunol. 167, 188-195.

Tosiek, M. J., Gruber, A. D., Bader, S. R., Mauel, S., Hoymann, H. G., Prettin, S., Tschernig, T., Buer, J., Gereke, M., and Bruder, D. (2011). CD4+CD25+Foxp3+ regulatory $\mathrm{T}$ cells are dispensable for controlling CD8 $+\mathrm{T}$ cell-mediated lung inflammation. J. Immunol. 186, 6106-6118.

Tsai, S., Clemente-Casares, X., and Santamaria, P. (2011). CD8(+) Tregs in autoimmunity: learning "self"control from experience. Cell. Mol. Life Sci. 68, 3781-3795. 
Wenkel, H., and Streilein, J. W. (1998). Analysis of immune deviation elicited by antigens injected into the subretinal space. Invest. Ophthalmol. Vis. Sci. 39, 1823-1834.

Yamada, S., Depasquale, M., Patlak, S. C., and Cserr, H. F. (1991). Albumin outflow into deep cervical lymph from different regions of rabbit brain. Am. J. Physiol. 261, H1197H1204.

Zhang, N., Schroppel, B., Lal, G., Jakubzick, C., Mao, X., Chen, D., Yin, N., Jessberger, R., Ochando, J. C., Ding, Y., and Bromberg, J. S. (2009). Regulatory $\mathrm{T}$ cells sequentially migrate from inflamed tissues to draining lymph nodes to suppress the alloimmune response. Immunity 30 , 458-469.

Zhang, X., Izikson, L., Liu, L., and Weiner, H. L. (2001). Activation of $\mathrm{CD} 25(+) \mathrm{CD} 4(+)$ regulatory $\mathrm{T}$ cells by oral antigen administration. J. Immunol. 167, 4245-4253.

Zhou, R., Horai, R., Mattapallil, M. J., and Caspi, R. R. (2011). A new look at immune privilege of the eye: dual role for the vision-related molecule retinoic Acid. J. Immunol. 187, 4170-4177.

Zhou, R., Horai, R., Silver, P. B., Mattapallil, M. J., Zárate-Bladés, C. R., Chong, W. P., Chen, J., Rigden, R. C., Villasmil, R., and Caspi, R. R. (2012).
The Living Eye "Disarms" Uncommitted Autoreactive T Cells by Converting Them to Foxp3+ Regulatory Cells following Local Antigen Recognition. J. Immunol. 188, 1742-1750.

Conflict of Interest Statement: The authors declare that the research was conducted in the absence of any commercial or financial relationships that could be construed as a potential conflict of interest.

Received: 26 March 2012; accepted: 03 June 2012; published online: 21 June 2012.
Citation: McPherson SW, Heuss ND and Gregerson DS (2012) Regulation of $\mathrm{CD}^{+} \mathrm{T}$ cell responses to retinal antigen by local $\mathrm{FoxP}^{+}$regulatory $T$ cells. Front. Immun. 3:166. doi: 10.3389/fimmu.2012.00166

This article was submitted to Frontiers in Immunological Tolerance, a specialty of Frontiers in Immunology.

Copyright (c) 2012 McPherson, Heuss and Gregerson. This is an open-access article distributed under the terms of the Creative Commons Attribution Non Commercial License, which permits non-commercial use, distribution and reproduction in other forums, provided the original authors and source are credited. 